\title{
Optimization the Removal of Nickel from Simulated Wastewater by A Pseudomonas aeruginosa Biofilm Supported on Clinoptilolite
}

\author{
Roghayeh Sadat Salehnezhad ${ }^{1}$, Mitra Ataabadi ${ }^{* 2}$ \\ 1. Department of Soil Sciences, Faculty of Agriculture \& Natural Resources, Isfahan (Khorasgan) Branch, \\ Islamic Azad University, Isfahan, Iran \\ 2. Department of Soil Sciences, Faculty of Agriculture \& Natural Resources and Waste and Wastewater \\ Research Center, Isfahan (Khorasgan) Branch, Islamic Azad University, Isfahan, Iran \\ *E-mail: mitra_ataabadi@yahoo.com \\ Received: 10 Jul 2018 ; Accepted: 2 Sep 2018
}

ABSTRACT
Background \& Objectives: Nickel toxicity and its bioaccumulation potential in organisms at high
concentrations, the use of cost-effective and environmental friendly remediation methods is necessary
for the removal of nickel from polluted water and wastewaters. Bacterial biofilm be able to remove
heavy metals from aqueous solutions and accumulate them in their cell structure. Therefore, the
purpose of this study was to evaluate the nickel removal efficiency by biofilms of Psendomonas aeruginosa
supported on clinoptilolite.
Methods: In this study, a strain of Psendomonas aeruginosa as a biofilm coating supported on
clinoptilolite. To ensure the establishment of biofilms, scanning electron microscopy was used. The
effect of concentration, pH, support medium dosage, temperature and contact time were evaluated in
5 levels, and finally, the results were assessed by adsorption isotherm models.
Results: The findings indicated that the maximum removal efficiency by biofilms of Pseudomonas
aeruginosa supported on clinoptilolite $(99 / 47 \%$ ) was achieved in optimal condition containing 900 mg.
$\mathrm{L}^{-1}$ of nickel concentration, pH of 9 , supporting medium dosage (clinoptilolite) 2.36 g. $\mathrm{L}^{-1}$, temperature
of $25{ }^{\circ} \mathrm{C}$ and the contact time of 45 days. The fitness of data in Freundlich adsorption isotherm
model revealed that the heterogeneity of adsorbent surface.
Conclusion: This study indicates that the use of biofilm coating on the surface of clinoptilolite, can
be a good candidate to remove the nickel from the aqueous media.
Keywords: Nickel, Clinoptilolite, Biofilm, Pseudomonas aeruginosa




\title{
بينه سازى ياكسازى نيكل از يساب شبيه سازى شده توسط بيوفيلم استقرار يافته باكترى سودوموناس آئروثرينوزا بر روى كلينويتيلولايت
}

\author{
رقيه سادات صالح نزاد'، ميترا عطآبادى"'P \\ ' كروه علوم خاك، دانشكده كشاورزى و منابع طبيعى، دانشكاه آزاد اسلامى واحد اصفهان (خوراسكان)، اصفهان، ايران انسان

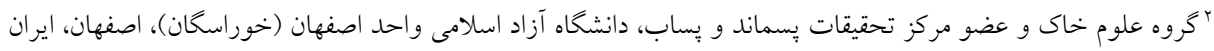

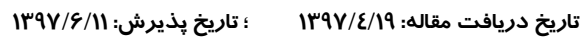

\section{حكيده}

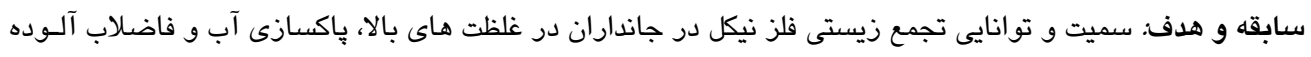

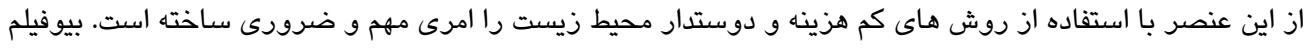

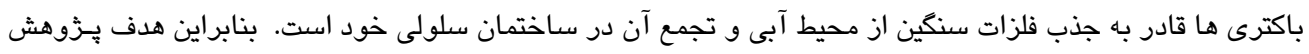

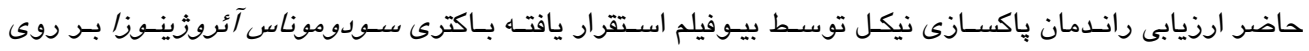
كلينويتيلولايت بوده است.

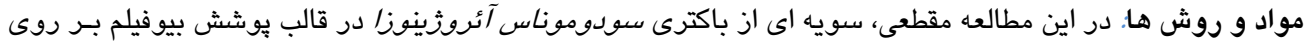

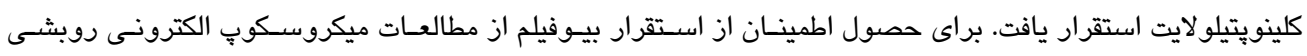

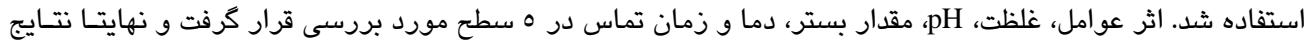
توسط مدل هاى همدماى جذب مورد ارزيابى قرار كرفت.

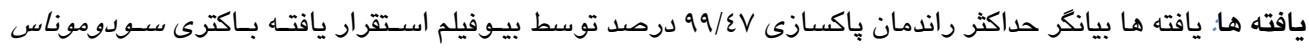

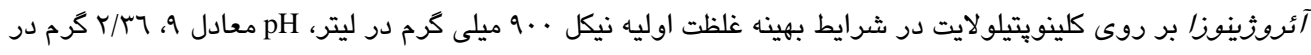

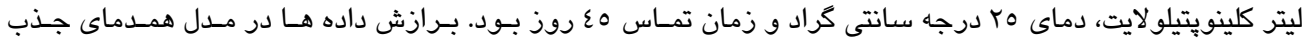

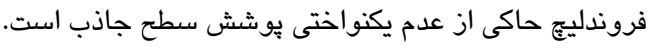

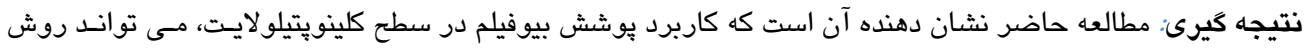
مناسبى براى پِاكسازى نيكل از محيط هاى آبى باشد. 
استفاده قرار كرفته اند، اما داراى معايب قابل توجهى از جملـه.

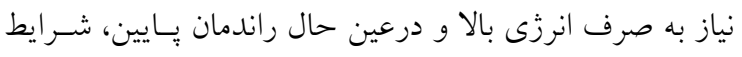

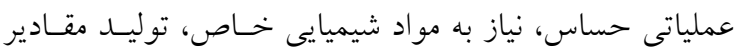

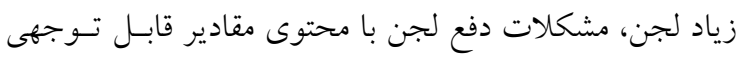

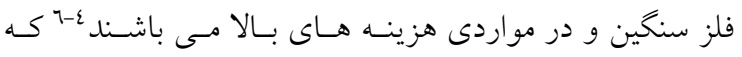

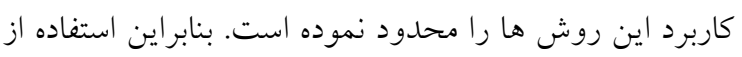

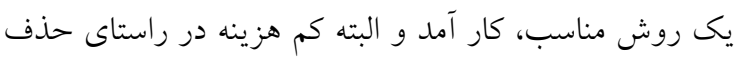

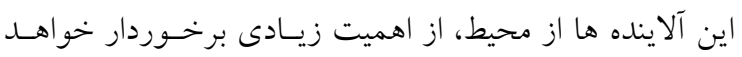

$$
\text { بود. }
$$

يديده ى جذب بيولوزيكى يكى فرآينـد متسابوليكى و غيـر

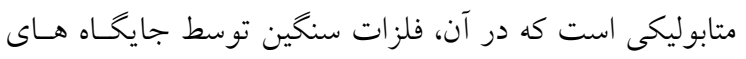

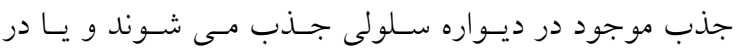

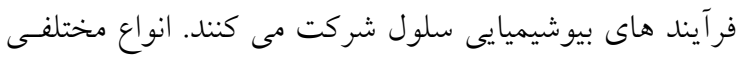

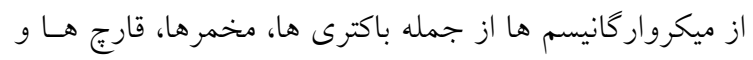

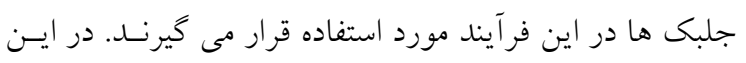

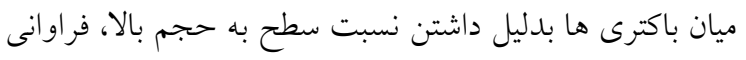

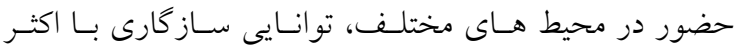

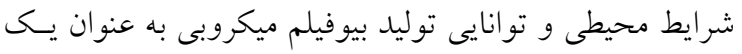

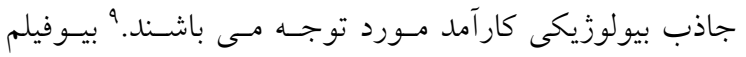

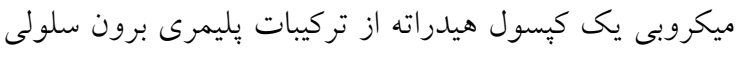
(EPS)

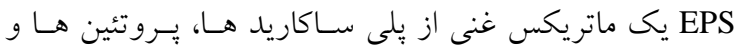
اسيدهاى نو كلئيك و همجينين حاوى جندين گروه فعال مانــــ

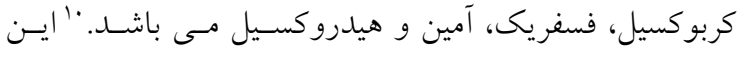

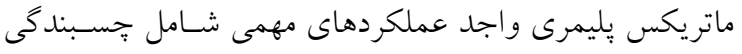

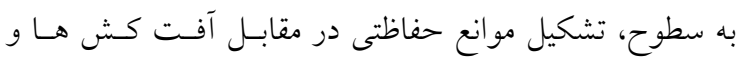

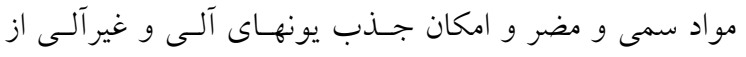

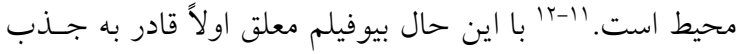

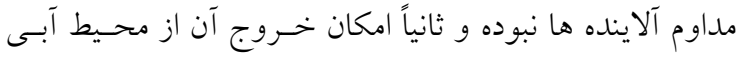

مقدمه

يكى از مهمتـرين مسـائل دنيـاى امسروز، آلـودكى محسيط زيست به فلزات سمى و خطرناى است. استخراج فلـزات از معادن و كاربرد كسترده فلزات سنخين در صنايع باعـث شـده

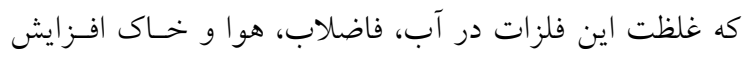
يابد.' تخليه انـواع بسـاب هـاى خـانكى، شـهرى، صـنعتى و زهكشى هاى كشاورزى سهم عمـده اى در ايسن آلـودكى هـا دارند. آلودگى يكى از مهمترين عو املى است كه باعـث هــدر

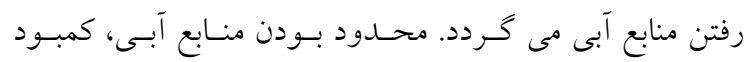
بارندگى، خطر بحران كـم آبسى در كشـور و اهميـت بازيـابى آنى

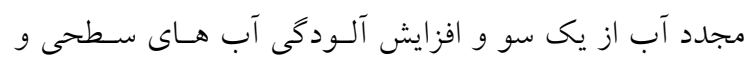
زيرزمينى به وسيله فلزات سنگين و ساير آلاينده هاى حاصـل از يساب هاى صـنعتى از سـوى ديخـر، يـافتن راه حـل هـاى زيست محيطى جهت حذف اين مواد از منابع را ضرورى مسى سازد. يساب هاى صنعتى حاوى مقادير قابل توجهى از فلزات

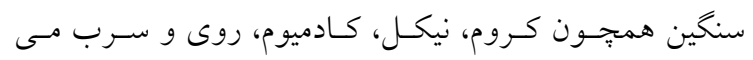
باشند. نيكل يكسى از فلـزات صـنعتى مهــم اسـت كـه در توليــ محصولات مختلف استفاده مى شـود. نيكـل از طريـق يُّـاب

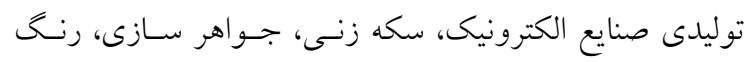
سازى، ساخت استيل هاى ضد زنخ و غيره به محيط زيست،

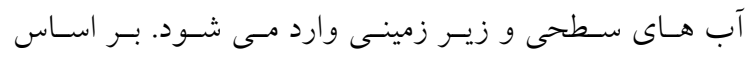

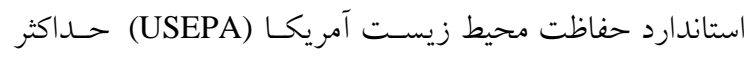
غلظت مجاز نيكل در يساب، ז/ • ميلى گرم در ليتر مى باشد. براى حذف فلزات سنخين از محسيط هـاى آبـى روشـهاى متعــددى از جملــه روش تبــادل يــونى، اسـتخراج حــلال،

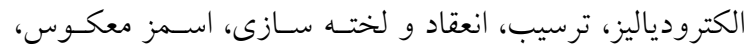
فيلتراسيون، جذب توسط كربن فعال و روشهاى غشائى ارائـه شده است. ع-ه كر جهه اين روشـها بـه طـور كسـترده اى مـورد 
رقيه سادات صالحنزاد و ميترا عطآبادى

جاذب زيستى به بارامترهاى مختلف فيزيكوشيميايى از جملـه

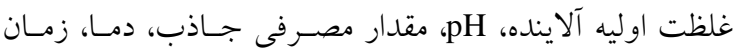

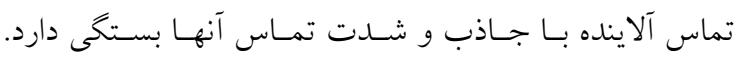

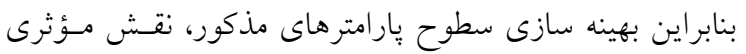

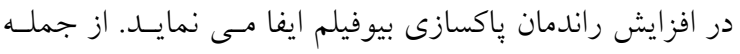
روش هاى بهينه سازى كه در سـال هـاى اخيـر مـورد توجـهـ

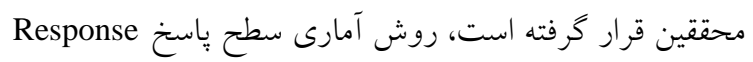

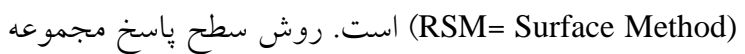

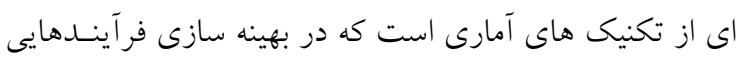

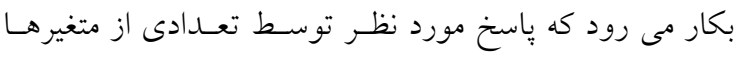

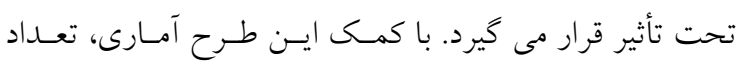

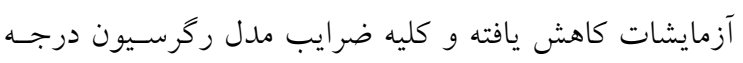

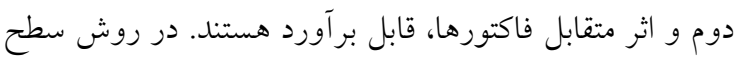

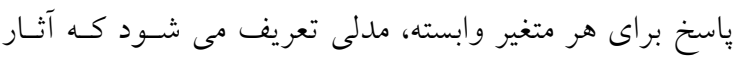

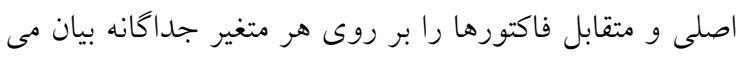
نمايد. r. بر اين اساس اهداف اين مطالعه شامل بهينه سازى سطوح

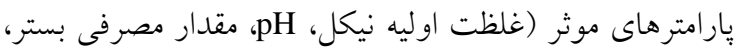

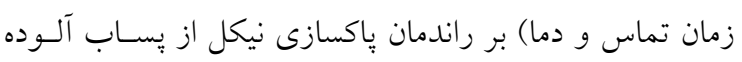

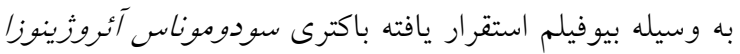

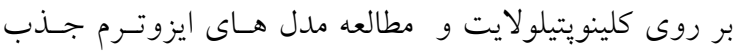
نيكل بوده است.

\section{مواد و روشها}

اين تحقيق يكى مطالعه تجربى -آزمايشگاهى اسـت كـه بــه

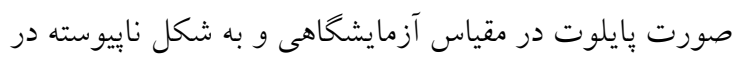
دانشخاه آزاد اصفهان (خوراسگان) انجام شدر.

\section{مطالعات ميكروبى و تعيين حداكثر غلظــت قابـل تحمل نيكل (MTC)}

جدايهاى از سودوموناس آئزو ثرينوزا كه در مطالعه ييشين،

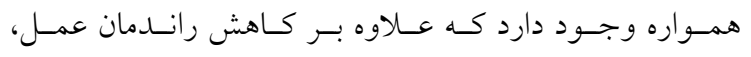
مشكلات راهبرى نيز به دنبال دارد. لذا در كاربردهاى زيست وارد

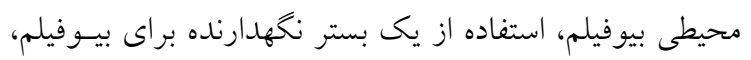

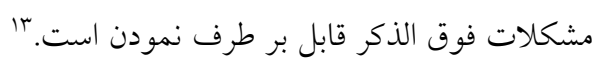

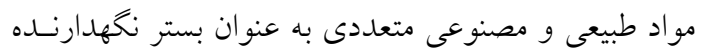

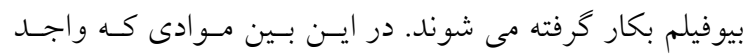

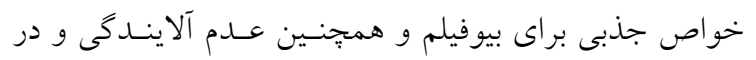

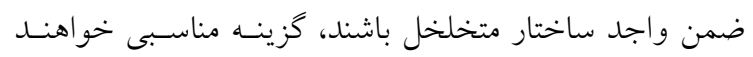

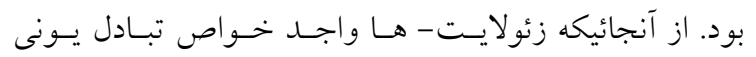

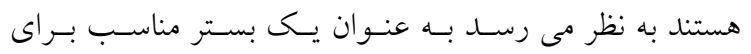

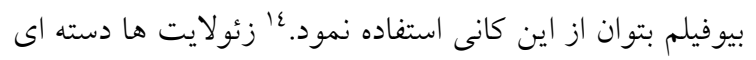

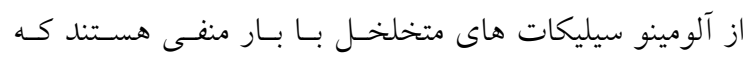

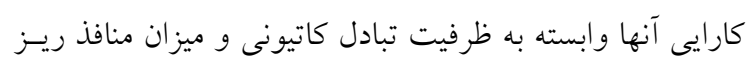
آنها است.

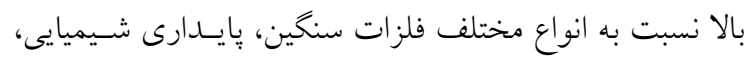

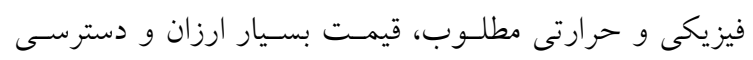

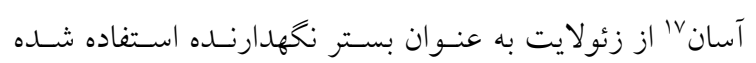

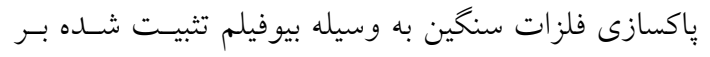

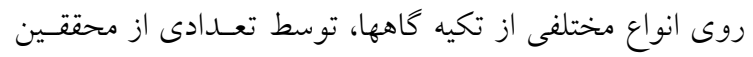

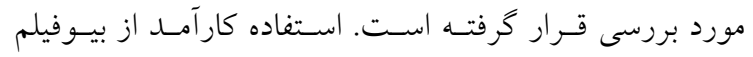

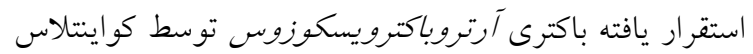

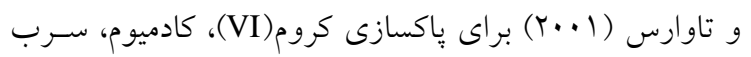

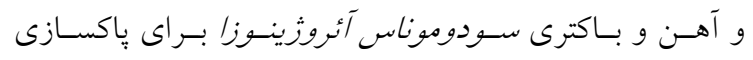

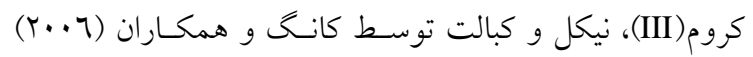

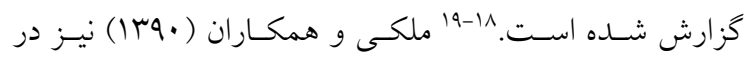

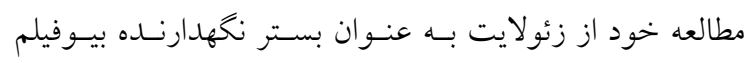

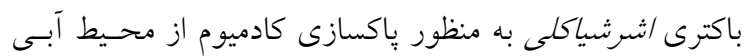

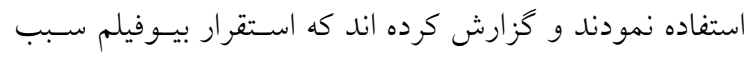

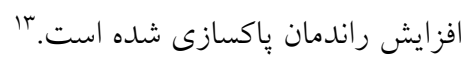

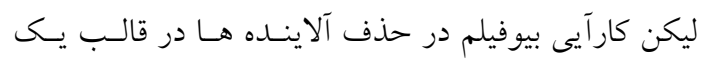


همراه حجم مشخصسى از محسيط كشـت بـاكترى مـورد نظـر وحجم مشخصى از غلظت هاى مختلف نيكـل بـه يـك ارلـن

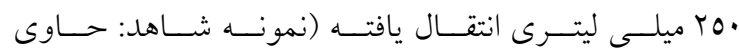
كلينويتيلولايت و فاقد باكترى بود) و به مدت 0 تا مع روز در

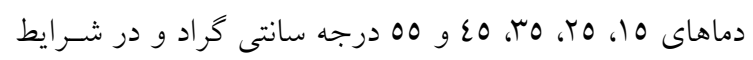
اختلاط ملايم (10 إدور در دقيقه) در انكوباتور شيكردار قرار داده شد. در نهايت غلظت نيكل در نمونسه هـاى صـاف شـده

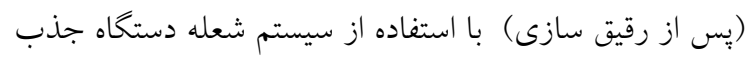

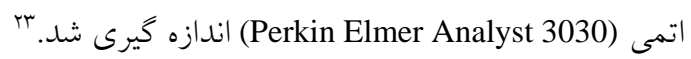

\section{مطالعات ناييوسته جذب}

آزمايشـات جـــب بـهـ صــورت ناييوسـته و بــا تغييـر

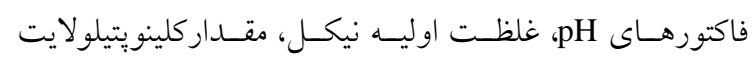
مصرفى، دما و زمان تماس انجـام گرفـت و در نهايـت نيكـل

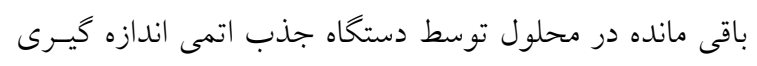
كرديد. بدين منظور براى بررسى اثر بار امترهاى فـوق و بهينـه.

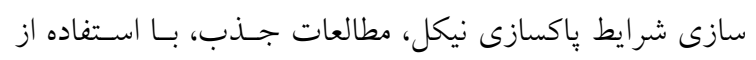
روش طراحى آزمايشات صـورت كرفـت. بـراى دسـتيابى بـه

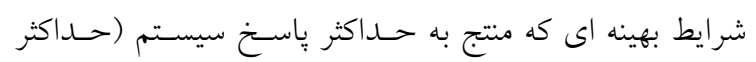

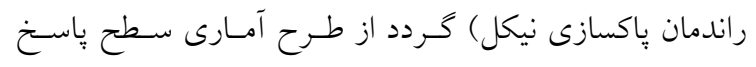
استفاده شد. بدين ترتيب كه اثر هر عامل در 0 سـطح (RSM) توسط طرح مركب مركزى (CCD) و در بr آزمايش بيشـنهاد شده توسط نرم افزار 7.00 Design expert در سه تكرار مورد بررسى قـرار كرفـت. حـــود تغييـرات يار امترهـاى مـؤثر بـر راندمان پاكسازى نيكل توسط جـاذب زيسـتى تهيـه شـده در جدول r ارائه شده است.
توانايى توليد بيوفيلم در حضور كـروم (VI) در آن بـه اثبـات

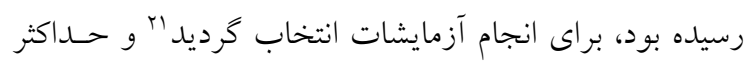
غلظـــت قابــل تحمــــل ) MTC=Maximum Tolerable (Concentration

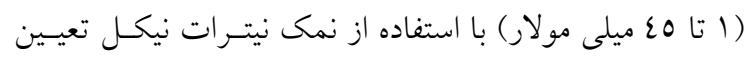
كرديد.

\section{Tاده سازى زئولايت طبيعى (كلينويتيلولايت)} كلينويتيلولايت مـورد اسـتفاده در ايسن مطالعسه از شـركت افرند توسكا تهيه كرديد كه خصوصيات فيزيكى -شـيميايى آن در جدول ا ارائه شده است. اين كانى با آسياب خرد شد و با تريكا استفاده از الك استاندارد ASTM با اندازه مش • rV دانه بندى گرديد. سيس براى حذف ناخالصى ها، جندين بار با آب شهر و آب مقطر شستشو داده شده و براى اصلاح اوليـه در دمـاى محيط خشك گرديد. اصلاح اوليه به وسـيله كلريـد ســيم 1 مولار به مدت زمان تماس VY ساعت صورت گرفت و نمونسه ها تا منفى شدن تست نيترات نقره، جندين بـار بـا آب مقطر شستشو داده شدند و در نهايت در دماى •7 درجه سانتى گراد

به مدت Tr إعت خشك گرديد.

\section{تثبيت بيوفيلم باكترى سودوموناس آئروثينوزا بر روى كلينويتيلولايت}

به منظور استقرار بيوفيلم باكترى سـودوموناس آئوزينـوزي بر روى كلينويتيلولايت، محيط كشت EMB به مدت ·r دقيقه در دماى |Y| درجه سانتيخراد اسـتريل شـده، سـيس بـاكترى هاى جداسازى شده به آن تلقيح شده و به مدت عاب ساعت و

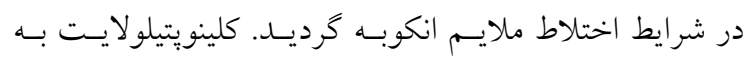

جدولا: خصو صيات فيزيكى و شيميايى زئولايت مورد استفاده

\begin{tabular}{|c|c|c|c|c|}
\hline \multicolumn{2}{|c|}{ خصوصيات شيميايى } & \multicolumn{3}{|c|}{ خصوصيات فيزيكى } \\
\hline كنجايش تبادل كاتيونى & فرمول شيميايى & درجه خلوص & وزن مخصوص (g.Cmº & حالت \\
\hline
\end{tabular}


رقيه سادات صالحنزاد و ميترا عطآبادى

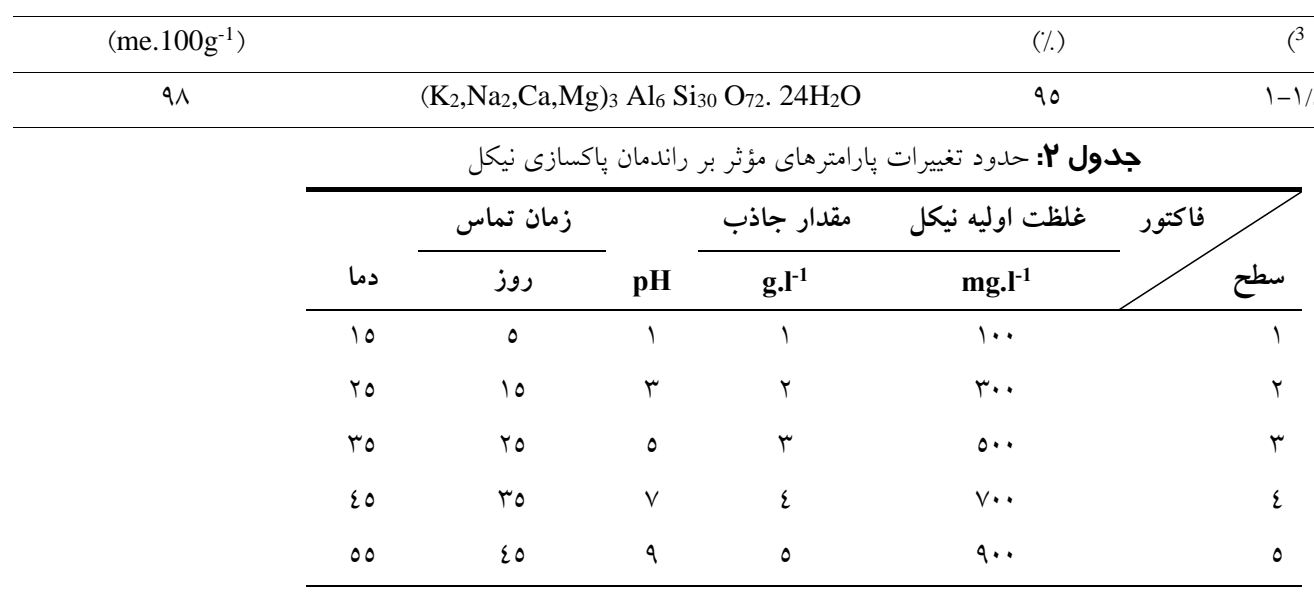

باكترى سودوموناس آئروزينوزا نشان داد كه اين جدايـه بـراى فلز نيكل داراى MTC معادل Or ميلى مولار بوده است.

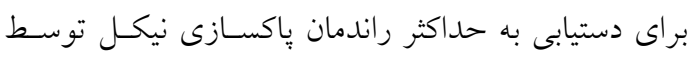
بيوفيلم استقرار يافته بر روى كلينويتيلولايت، اقــام بـه بهينـــ سازى 0 متغير معرفى شده توسط روش آمارى RSM كرديـد. بر اين اساس rr آزمايش اجرا گرديد كه نتايج آناليز آمـارى و

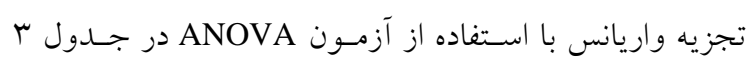
ارائه شده است.

با توجه به جدول ب اثـــ يـارامتر هـاى pH و زمـان و اثـر نماى دوم غلظت و pH بر راندمان پياكسـازى نيكـل معنى دار شده است. با توجه به يارامتر ميـانگين مربعـات در جـدول مب، pH بـا

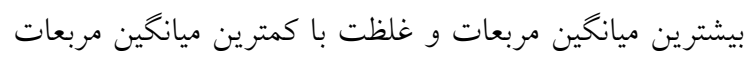

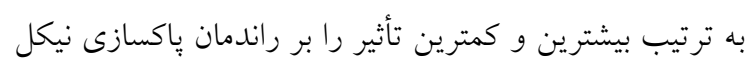
داشته اند. به منظور ارزيابى صحت برازش و دقت مــل يسيش بينى شده به روش سطح ياسخ، كليـه آناليزهـاى آمـارى در سـطح

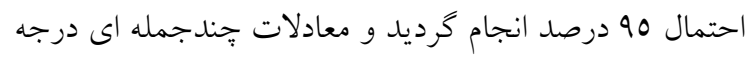
اول و درجه دوم براى فلز نيكل به منظور بيش بينسى رانــدمان

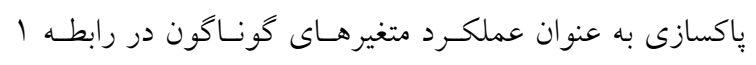
ارائه شده است.
براى حصول اطمينان از صحت شـرايط بهينسه يسيش بينى شده توسط روش سطح پِاسخ، راندمان پياكسازى نيكـل بـراى

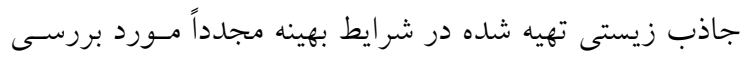
قرار كرفت.

\section{مطالعات مربوط به ايزوترم جذب}

براى تعيين بهترين رابطـه توصسيف كنتـده جـذب نيكـل، ميزان جذب در حضور غلظت هاى مختلـف نيكـل (· (1، rO،

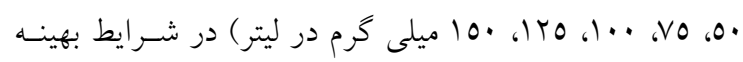
بدست آمده از روش سطح باسـخ تعيسين كرديـــ و داده هـاى

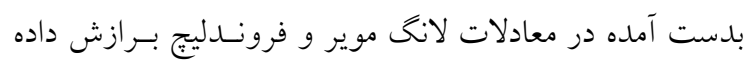
شد. ب ب

\section{تعيين مورفولورى جاذب}

در نهايت براى حصول اطمينان از استقرار بيوفيلم بر سطح كلينويتيلولايـت اقــام بــه تهيـهـ تصـوير بــه وسـيله دسـتخاه SEM= Scanning Electron ) ميكروسكوبّ الكترونى روبشى مدل (Microscopy

يافتهها

نتايج بررسى حداكثر غلظـت قابـل تحمـل نيكـل توسـط 
بهينه سازى پِاكسازى نيكل از يֶاب شبيه سازى شده توسط بيوفيلم استقرار يافته باكترى سودوموناس آئروثينوزا بر روى كلينويتيلولايت $\cdot / 79 r E+\cdot / 101 \mathrm{BD}+\cdot / \cdot r 9 \mathrm{DE}+1 / / 9 \Lambda \mathrm{r} 7 \mathrm{~A}^{2}+1 / N T V \mathrm{~B}^{2}$

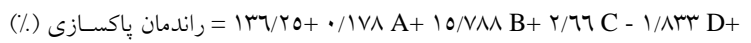

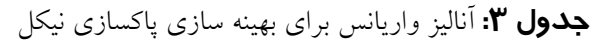

\begin{tabular}{|c|c|c|c|c|}
\hline P-Value & F Value & ميانخين مربعات & درجه آزادى & منبع \\
\hline$<\cdot / \cdots+1$ & $1 T / 90$ & $1.71 / 92$ & $\wedge$ & مدل \\
\hline - /NOT. & •/.rר & T/QT & 1 & A: غلظت \\
\hline 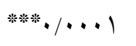 & $09 / 01$ & ¿AVN/QT & 1 & $\mathrm{pH}: \mathrm{B}$ \\
\hline$\cdot / T V \varepsilon V$ &.$/ 19$ & $r r / v \varepsilon$ & 1 & C: مقدار بستر \\
\hline$\cdot /|r \varepsilon|$ & $r / 00$ & $\Lambda \cdot r / 9 r$ & 1 & D: دما \\
\hline$* / \cdot 710$ & $r / 70$ & $r 99 / 07$ & 1 & E Eمان \\
\hline.$/ 1100$ & $1 / 90$ & $|7 \cdot / r|$ & 1 & $\mathrm{BD}$ \\
\hline.$/ 1997$ & $1 / N \varepsilon$ & $\mid \varepsilon Y / Q 1$ & 1 & $\mathrm{DE}$ \\
\hline *****ar & $1 N / 10$ & $1020 / 49$ & 1 & $A^{r}$ \\
\hline \multirow[t]{2}{*}{ 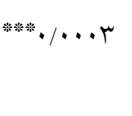 } & $|V / 7|$ & $\mid \varepsilon \varepsilon r / \mu \wedge$ & 1 & $\mathrm{~B}^{r}$ \\
\hline & & $11 / 91$ & r & خطاى باقى مانده \\
\hline \multirow[t]{3}{*}{$* / \cdot 7 r 7$} & $\varepsilon / 90$ & $99 / 19$ & 11 & عدم برازش \\
\hline & & $r \cdot / \cdot \varepsilon$ & 0 & خطاى كل \\
\hline & & & r & كل \\
\hline
\end{tabular}
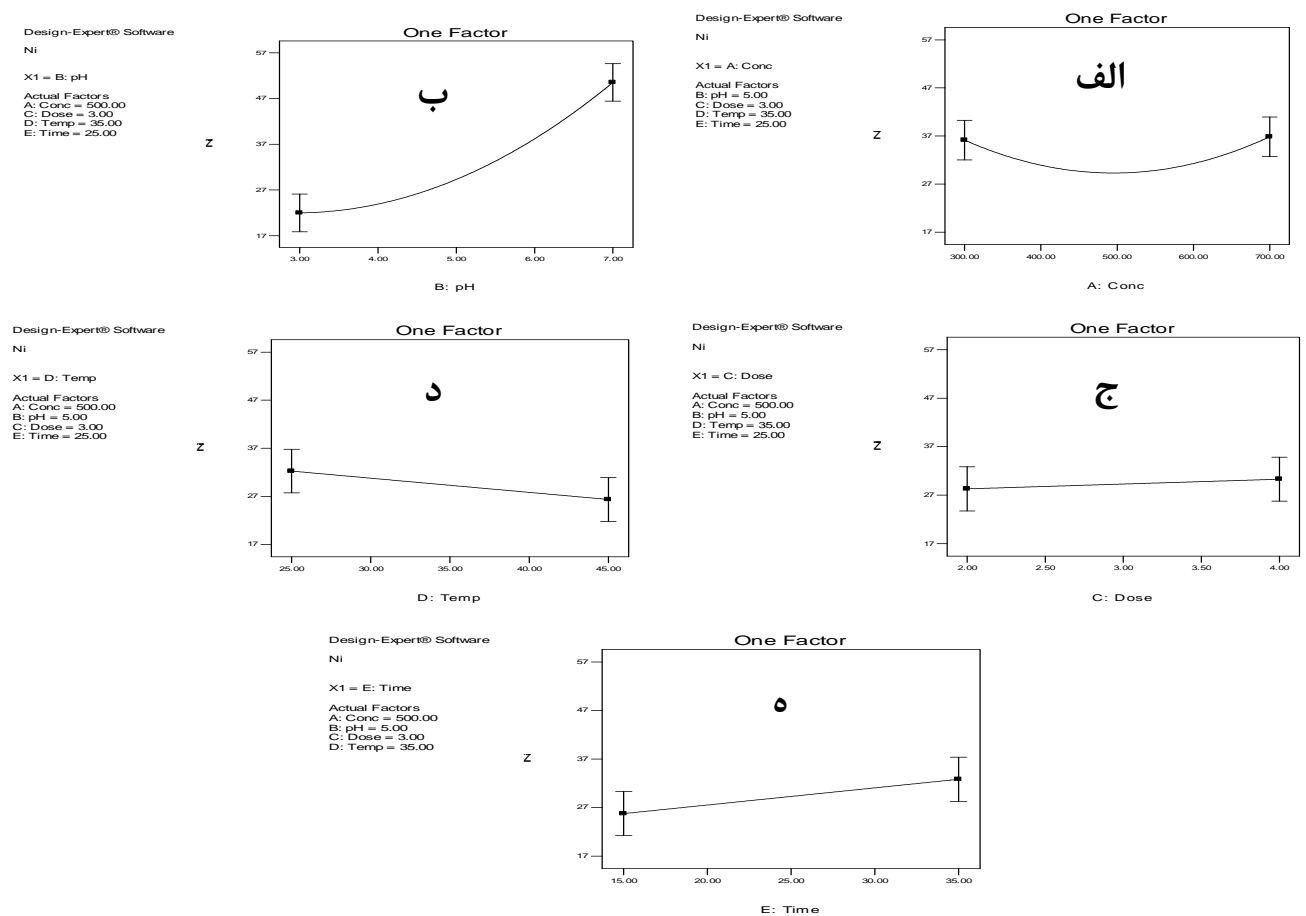


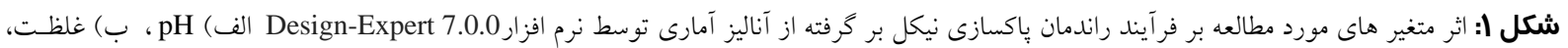
ج) دما، د) مقدار كلينويتيلولايت مصرفى، ه) زمان در رابطه ا، ضريب منفى و مثبت يار امترهاى مورد مطالعه، است. r- نمودار (ب): اين نمـودار بـــراكنش بـاقى مانسده هـا به ترتيب نشان دهنده رابطه معكـوس و مسـتقيم بـين يـارامتر

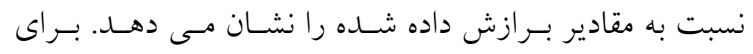
بررسى فرض ثابت بودن واريانس باقى مانده هـا، در صـورتى كه در اين نمودار روند خاصى ديده نشود، فرض ثابست بـودن واريانس هم يذيرفته مى شـود. در نمــودار رونـــ خاصسى كـهـ نشان دهنده زياد شدن يا كم شدن واريانس باشد، ديـده نمسى لــ شود، بنابراين فرض ثابت بودن واريانس نيز يذيرفته مى شود.

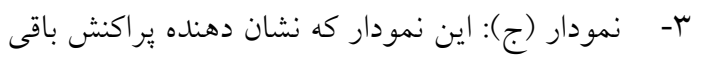

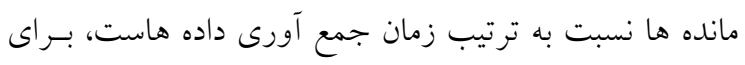
بررسى استقلال بين باقيمانده هاست. در صورت عدم مشاهده روند خاصى ( مانند سينوسى بـودن) در ايـن نمـودار، فـرض مورد نظر يذيرفته مى شود. با توجـهـ بــه عـدم مشـاهده رونـا خاص در نمودار، فرض استقلال باقيمانده ها نيز يذيرفتسه مسى بـ بـ بنابراين با توجه به تحليل نمـودار ب و مـورد قبـول واقـع شدن فرض هاى مطرح شده، مدل انتخاب شده بـراى تحليـل داده ها مناسب است.

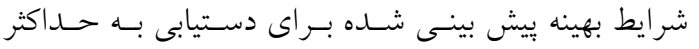
راندمان ياكسازى نيكل توسط روش سطح پِاسخ شامل غلظت اوليسه حسـود .9 ميلسى گـرم در ليتـر، pH معسـادل 9، مقـدار كلينويتيلولايت مصرفى حس/ץ گرم در ليتر، زمان تماس و دماى 0r درجه سـانتيخراد بـود و اجـراى آزمـايش در ايسن شرايط با راندمان 99/0 درصد همراه بود.

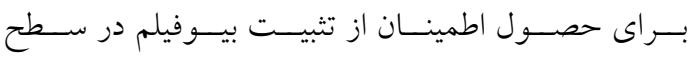
كلينويتيلولايست از تصساوير ميكروسـوبٍ الكترونسى روبشى

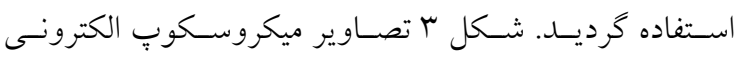
روبشى بيوفيلم تثبيت شده را در شرايط عدم حضور و حضور • . . ميلى كرم در ليتر نيكـل نشـان مسى دهـد. يوشـش ذرات مورد نظر و راندمان ياكسازى است. همانطور كـه در شـكل 1 نيز مشاهده مى شـود، در بررسسى اثــر يارامترهـاى اصـلى بــر راندمان ياكسازى نيكل با افزايش pH، مقـدار كلينويتيلولايـت مصرفى و زمان، راندمان پِاكسازى نيكل افزايش و بــا افـزايش دما، كاهش يافته است. در ارتباط با فاكتور غلظت، اين رابطـه

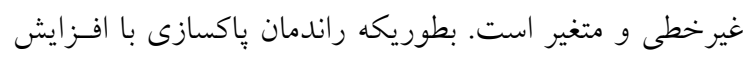
غلظت، در ابتدا كاهش و سيس مجدداً افز ايش يافته است.

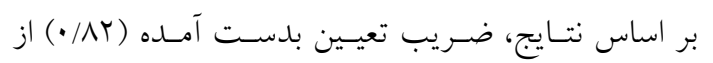
ضريب تعيين بيش بينى شده توسط مدل (2010) بيشـتر بـوده به منظور تائيد مدل سطح ياسخ، ترسيم توزيعى داده هـاى آزمايش در مقابل مقادير بيش بينى شده توسط مدل در شـل

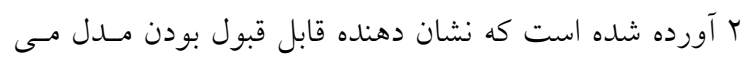
باشد. تحليل نمودار باقى مانده ها براى ارزيابى تناسب مدل بر سه فرض استوار مى باشد: ا . باقيمانده ها داراى توزيع نرمال با ميانخين صفر باشند. r. باقيمانده ها واريانس ثابت داشته باشند. r. باقيمانده ها مستقل باشند. جانجه اين سه فرض درست باشــند، مـدل انتخـاب شــده معتبر مى باشد، در غير اين صورت بايـــ مــل ديخـرى بـراى بررسى داده ها انتخاب شود. بررسى درسـى ايسن فـرض هـا

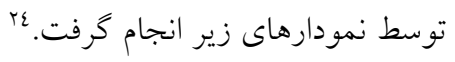
- - نمودار (الف): نمودار p-p اسـت كـهـ بــراى بررسى نرمال بودن باقيمانده ها مى باشد. اگر نقاط باقيمانده ها به خط نزديك باشند، بيان كننده نرمال بودن باقى مانده هـا اسـت. در اين نمودار انحرافى در نرمال بودن باقى مانده هـا ديــده نمسى شود، بنابراين فرض توزيع نرمـال باقيمانسـه هـا مـورد قبـول 
بهينه سازى پِاكسازى نيكل از يֶاب شبيه سازى شده توسط بيوفيلم استقرار يافته باكترى سودوموناس آئروثينوزا بر روى كلينويتيلولايت

$$
\begin{aligned}
& \text { كلينويتيلولايت بـه واسـطه يلسى سـاكاريدهاى بـرون سـلولى } \\
& \text { باكترى سودوموناس آئروزينوزا در تصوير (ب) به خوبى قابل } \\
& \text { رويت است. }
\end{aligned}
$$
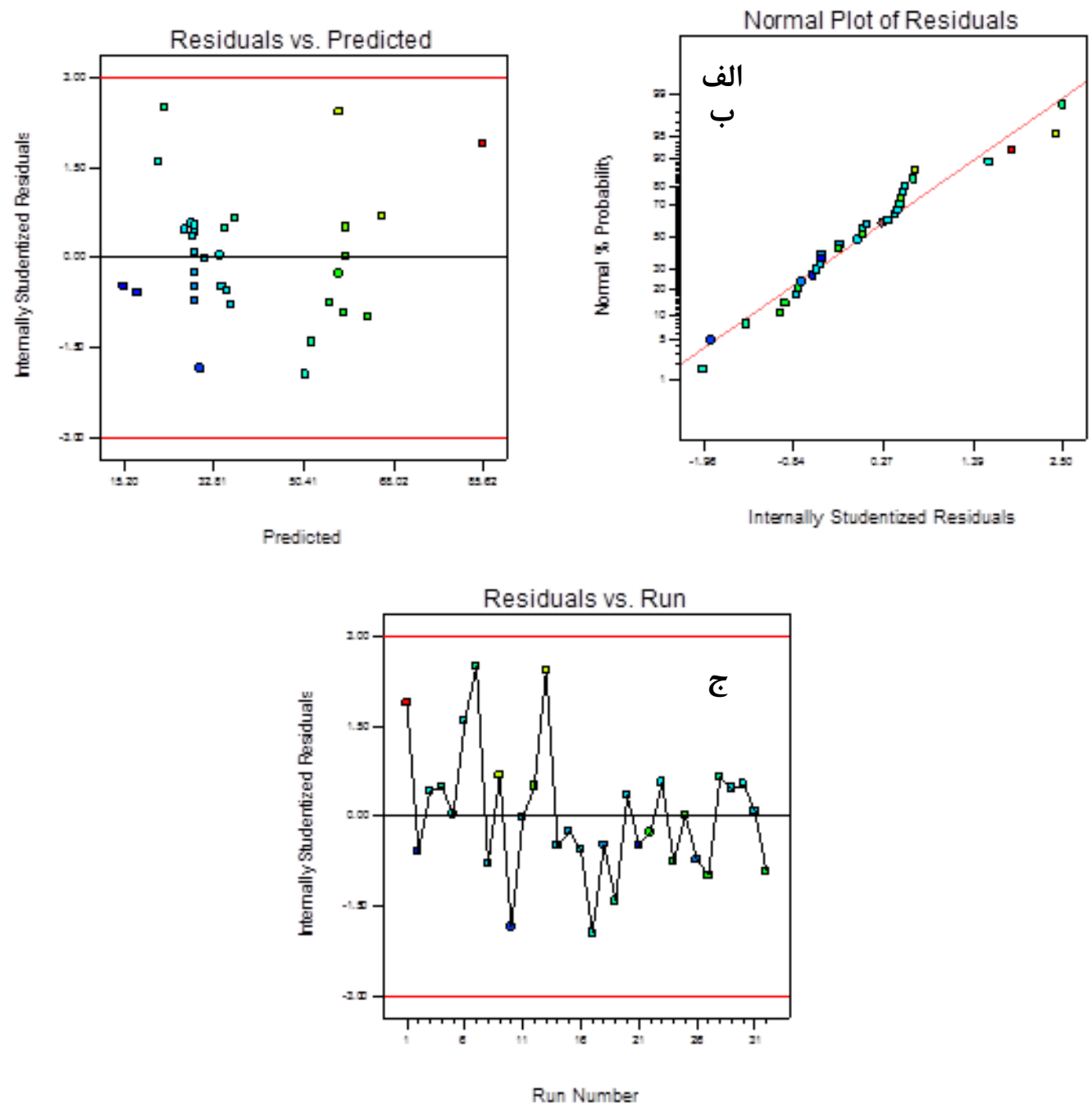

شكل r: ترسيم توزيع داده هاى آزمايش در مقابل مقادير ييش بينى شده مدل 
رقيه سادات صالحنزاد و ميترا عطآبادى
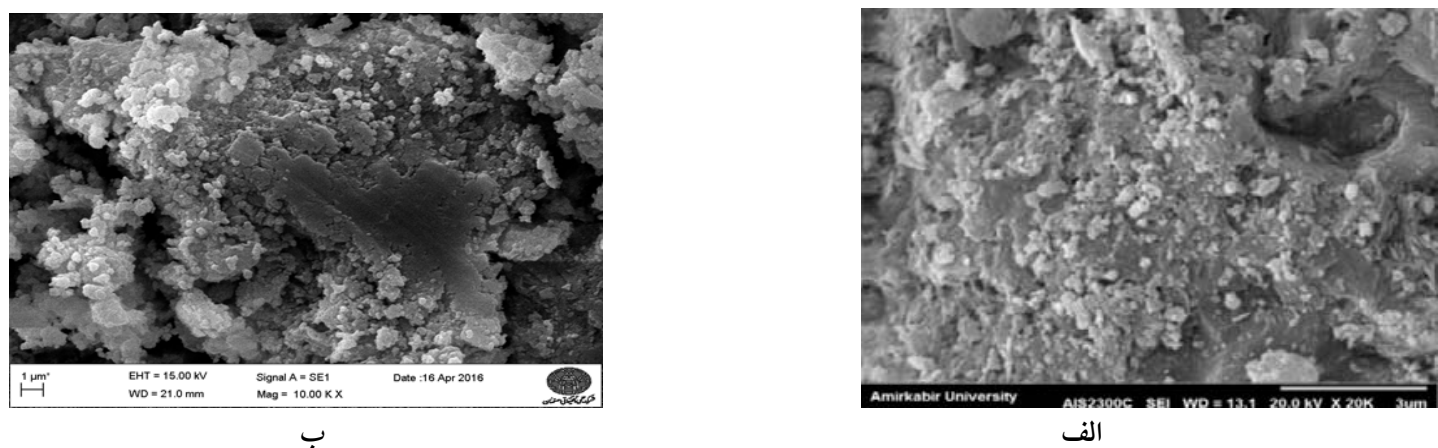

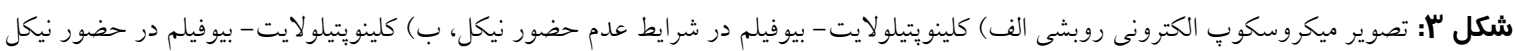

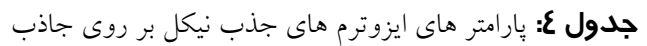

\begin{tabular}{|c|c|c|c|c|c|}
\hline \multicolumn{3}{|c|}{ فروندليج } & \multicolumn{3}{|c|}{ لانگ موير } \\
\hline \multicolumn{3}{|c|}{$Q_{i}=K_{f} Q_{i}^{1 / n}$} & \multicolumn{3}{|c|}{$Q_{r}=\frac{\left(Q_{\max } b C_{s}\right)}{\left(1+b C_{n}\right)}$} \\
\hline $\mathrm{R}^{2}$ & $1 / \mathrm{n}$ & $\mathrm{K}_{\mathrm{f}}$ & $\mathrm{R}^{2}$ & $\mathrm{Q}_{\mathrm{m}}\left(\mathrm{mg} \cdot \mathrm{g}^{-1}\right)$ & $\mathrm{b}\left(\mathrm{l} \cdot \mathrm{mg}^{-1}\right)$ \\
\hline.$/ 991$ & r & 1/7rr &.$/ 90 \varepsilon$ & $\varepsilon \vee V 7 / 19$. & $\cdot / r \varepsilon 1$ \\
\hline
\end{tabular}

جدايه در تحمل اين فلز در محيط بوده و معادل Or ميلى مولار برآورد شده است. حداكثر غلظت قابل تحمل فلزات در واقـع غلظتى از فلزات است كه در غلظت هاى بالاتر از آن، بـاكترى

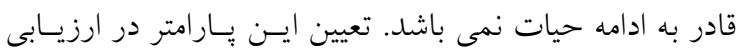
مقاومت باكترى در محيط هاى آلوده مى تواند بسيار مفيد واقع شود. در مطالعات صـورت گرفتـه، MTC نيكـل بــراى انسواع باكترى هاى موجود در يساب هاى حاوى نيكل بسيار متفاوت

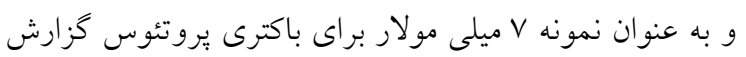

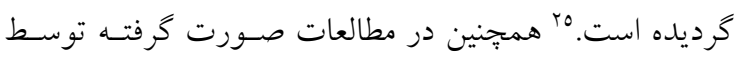

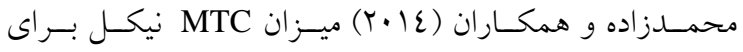
باكترى هاى /ستافيلوكوكوس و باسيلوس به ترتيب برابر • آب

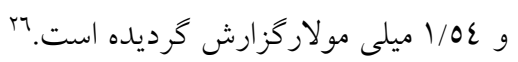
در مطالعات مربوط به جداسازى و شناسايى باكترى هـاى رك رك مقــاوم بــه فلـزات ســخين، حضــور بــاكترى سـودوموناس آئروثينوزا در بين باكترى هاى مقاوم جداسازى شده به كرات

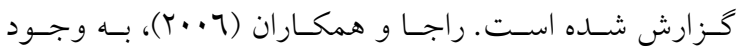
مقاومت جند كانه به فلزات نيكل، سرب، كادميوم و كـروم در
نتايج برازش داده هاى جذب نيكل توسط بيوفيلم استقرار يافته در مدل هاى لانخ موير و فرونــليج در جــدول ع ارائسه شده است. گرجهه داده هاى جذب نيكل بـه خــوبى در هـر دو

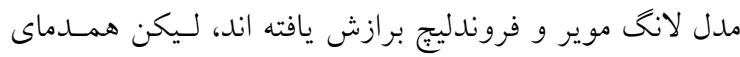
فروندليج قادر به توصيف بهتر فرآيند جذب نيكل بوده است.

بحث

تشكيل بيوفيلم يك مكانيسم ساز گارى است كـه مقاومـت

باكترى ها را در مقابل عوامل نامساعد محيطى در مقايسـه بــا سلول هاى يِانكتونيك به ميزان قابل توجهى افزايش مى دهد. از جمله عوامل نامساعد محيطى، حضـور فلـزات ســخين در محيط رشد باكترى هاست، بطوريكه حضور نيكل در محيط به عنوان فلزى سمى و خطرناك منجر بـهـ تحريسك ترشـح پيلى ساكاريدهاى برون سلولى توسط باكترى گرديــده، مقاومست و ساز گارى آن را افزايش مى دهد. بطوريكه نتايج بررسى MTC در جدايه سودوموناس آئروثينوزا، حاكى از توان بـالاى ايسن 
حضور و عدم حضور بيوفيلم باكترى اشريشـيا كلى گـزارش

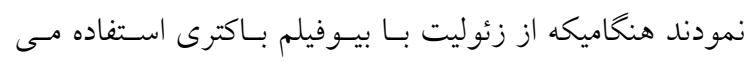

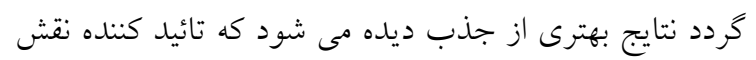

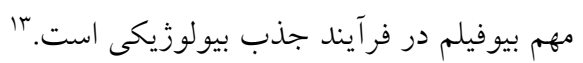

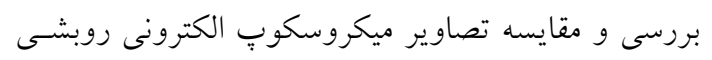

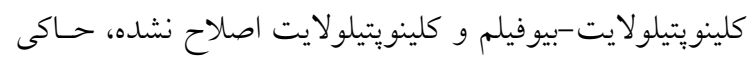

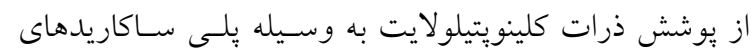

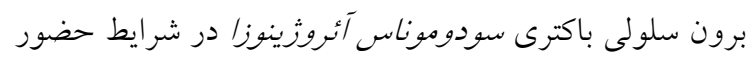

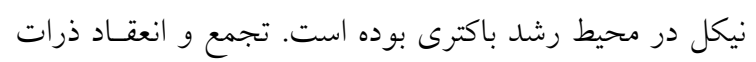

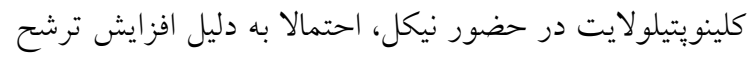

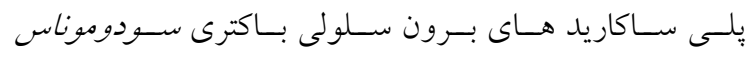

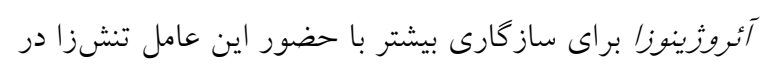

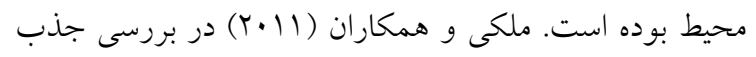

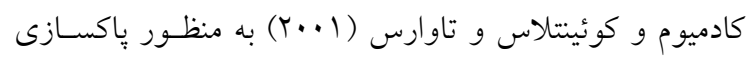

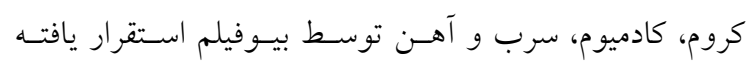

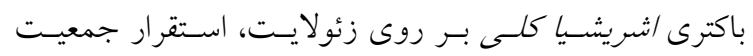

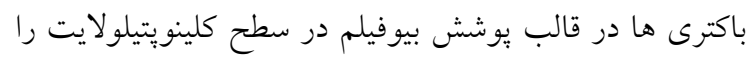

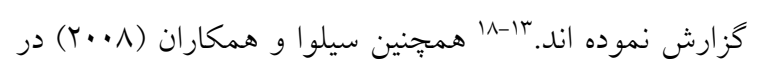

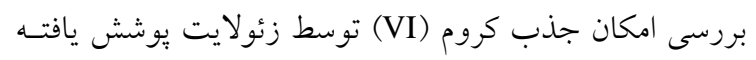

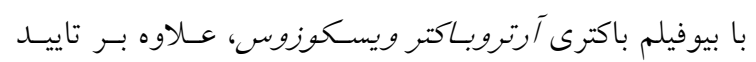

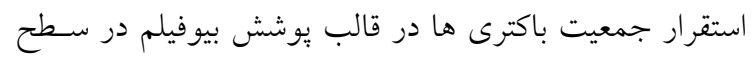

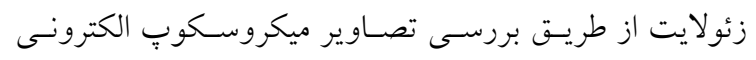

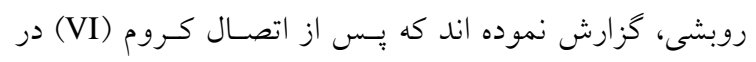

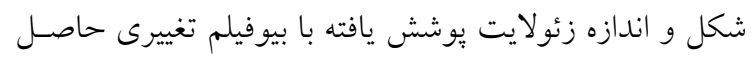

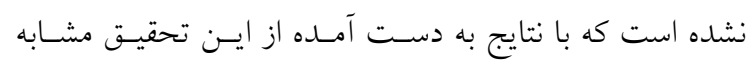
است. "r در فرآيند جذب، غلظت اوليه يون هاى ماده جذب شونده

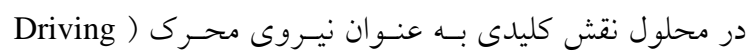

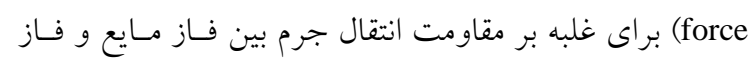

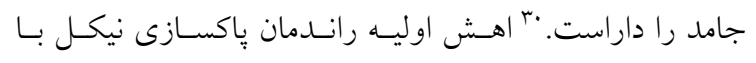

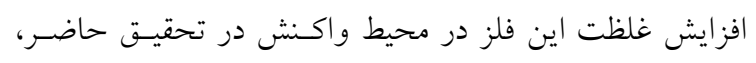

باكترى سودوموناس آئروزينوزا اشاره نموده اند.

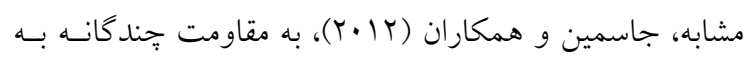

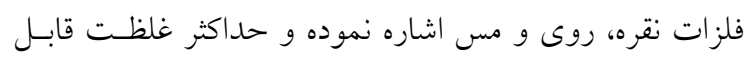

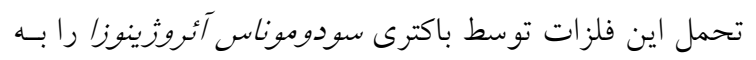

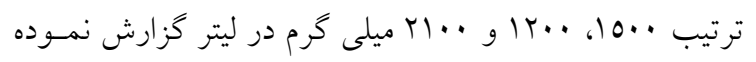

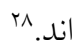

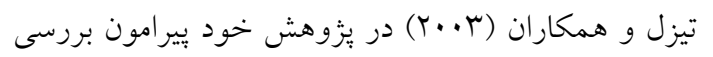

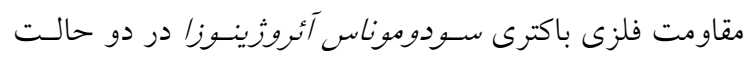

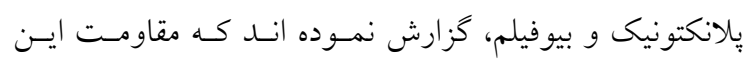

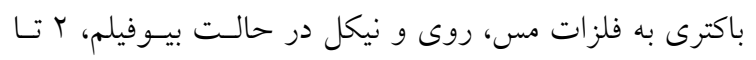

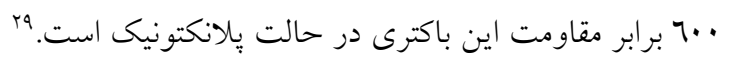

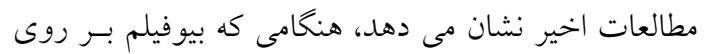

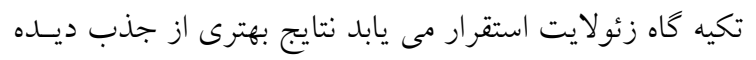

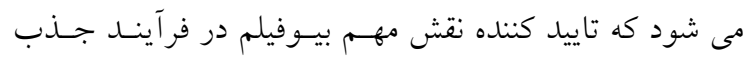

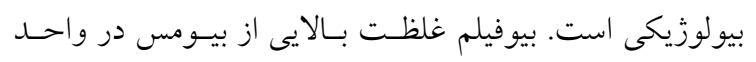

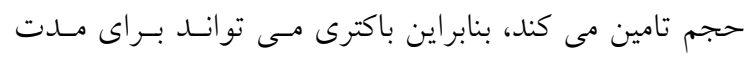

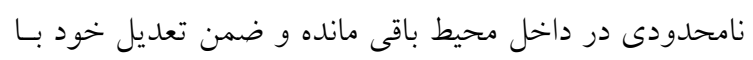

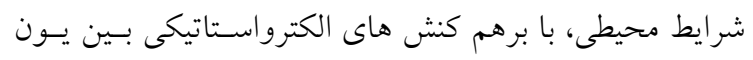

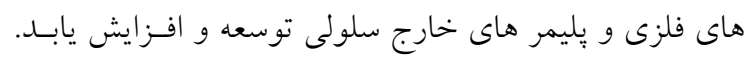

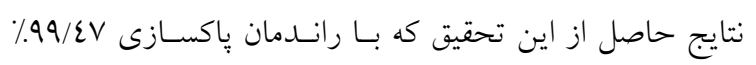

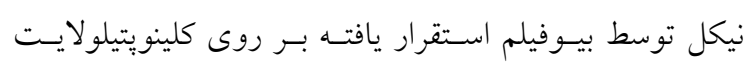

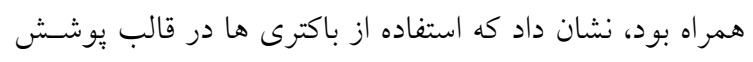

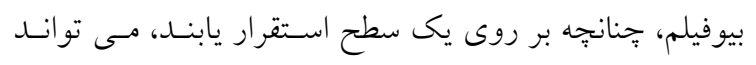

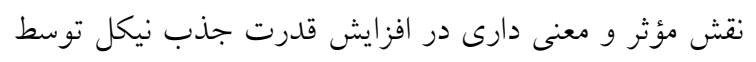

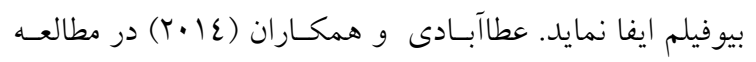
خود گزارش نمودند كه حضور كروم (VI) در محيط به عنو اندان فلزى سمى و خطر ناك منجر به تحريكى ترشح پيلى سـاكاريد هاى برون سـلولى توسط بـاكترى سـودوموناس آئروثينسوزا

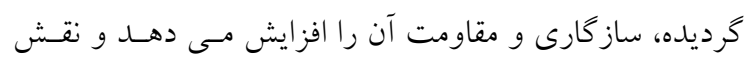

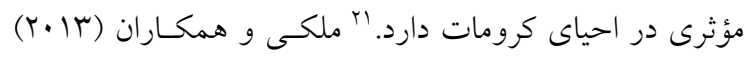
نيز در مقايسه جذب يونهاى كادميم توسط زئوليت در شـر ايط درون 
رقيه سادات صالحنزاد و ميترا عطآبادى

دليل از دست دادن يروتون توسط گروه هاى عامل موجـود در

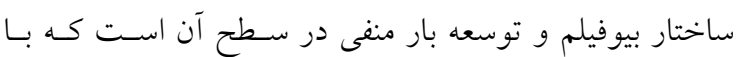

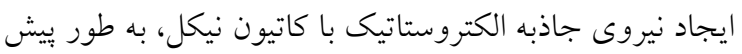
رونده اى باعث افزايش جذب بيولوزيكى نيكل تا زمـانى كـه

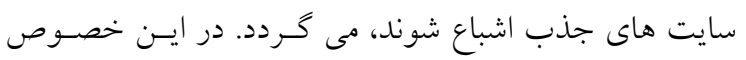
كامت و همكاران اظهار نموده انــ كـهـ شـكل بــدون بروتـون سايت هاى فعال جـــب كـه اساسـا خـروه هــاى كربوكسـيل، فسفريك و آمينو هستند، عمدتا مسئول اتصال يون هاى فلزى

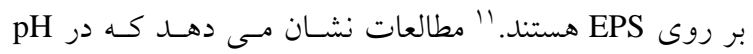
هاى بالاتر از 9، برخى از كاتيون هاى فلـزى مانتـــ نيكـل بـــ صورت هيدرو كسيد نيكل رسوب خواهد نمود و در هH هـاى كمتر از 7 جذب بيولوزيكى مى تواند به دليل رقابت بين يـون نيكل و يون هيدروزن براى سايت هاى جذب موجود بر سطح سلول ميكروبى، كاهش يابد. مضاف بر اينكه اكثر گـروه هــاى كربوكسيل موجـود بـر روى سـطح سـلولهاى بـاكترى امكـان يونيزه شدن نداشته و بصورت غير يونى باقى مانده و لذا قادر به جذب فلز از محيط مايع نيستند. ميزان مصرفى بستر يا تكيه گاه يكى از مهم ترين بارامترها در فرآيند جذب بيولوزيكى توسط بيـوفيلم اسـت، زيــرا مسى تواند بر قدرت اتصال باكترى و نخهارى آن در قالب يوشـش بيوفيلم اثر بخذارد. افزايش اندك رانـدمان ياكســازى نيكـل در ازاى افزايش مقدار مصرفى بستر بـهـ بـيش از ا خــرم در ليتـر، احتمالا به واسطه استقرار بهتر بـاكترى هـا در قالـب سـاختار بيوفيلم و متعاقبا افزايش تعداد جايخاههاى فعال قابل دسترس براى جذب نيكل توسط گروه هاى عامل موجــود در سـاختار بيوفيلم بوده است. در مطالعه اى مربوط به جذب يون نيكل و مس، اسماعيلى و همكاران (9 (Y) به نتـايج مشـابهى دسـت يافته اند. كروم (VI) توسط بيوفيلم استقرار يافته بـاكترى سـودوموناس آئروزينوزا بر روى كلينويتيلولايت، افزايش رانـدمان ياكسـازى به ازاى افزايش مقدار كلينويتيلولايت مصرفى را گزارش نموده
احتمالا به دليل يرشدن جايخاهمهاى جـــب خـالى و كـاهش شـيب غلظـت نيكـل بـه سـمت جـاذب اسـت. هورسـفال و

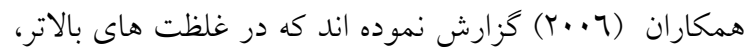
كاهش فاصله بين كونه هاى جذب شونده در سـطح جـاذب، توزيع بار در سطح بيوفيلم راتحت تاثير قـرار داده و توانـايى كونه ها براى مهاجرت به سطح توده زيستى را تغيير مى دهـد

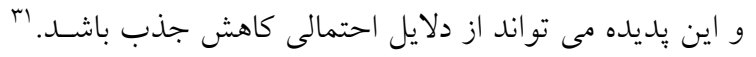

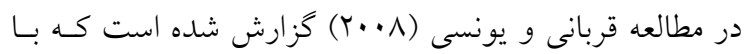
افزايش غلظت اوليه، تعداد يون هـاى در حـال رقابـت بــراى واكنش با كروه هاى فعال سطح جاذب بيشتر مسى شـود و در نتيجه مكان هاى فعال جاذب اشـباع مسى گـردد. بَ حيـدرى و همكاران (Y (Y) در خصوص حذف مخلوط يون هاى فلـزى

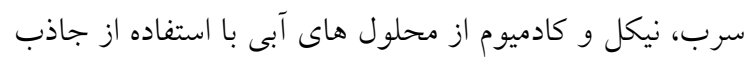

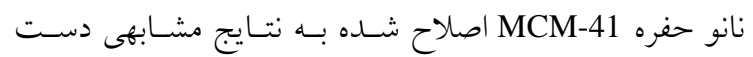

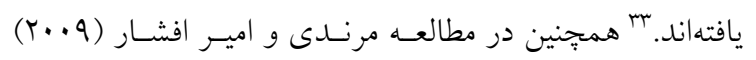
بيرامون جذب بيولوزيكى سرب و روى به وسيله بيومس غيـر

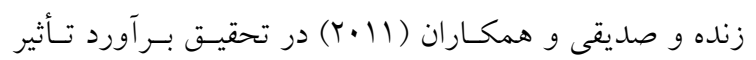
بارامترهاى مهم در جـــب بيولـوزيكى مسس و منخنـز توسـط باكترى باسيلوس توزنجينسيس و آسـمان رفعـت و همكـاران

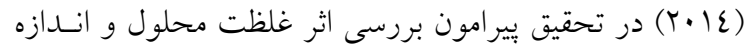
ذرات زئولايت بر جذب نيكل، كـادميوم و سـرب از محلـول آبى، نتايج مشابهى ارائه شده است. عَro-ro-ror

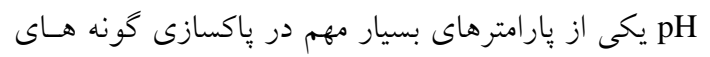

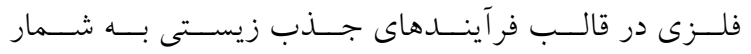
مى آيد. زيرا pH محلول، رفتار گونه هاى فلزى را بـه واسـطه نقشى كه در امكان اتصال آنهـا بـه اخزويلسى سـاكاريدها دارد، تحت تاثير قرار مى دهد. در حقيقـت بـار خــروه هــاى عامـل موجود در اگزويلى ساكاريدها، به واسطه عمل بيروتون كيسرى و يروتون زدايى تغيير يافته و از اين جهت، جذب و دفع گونه

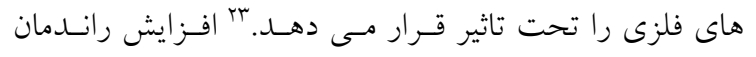
ياكسازى نيكل به واسطه افزايش pH محيط در اين مطالعه بـه 


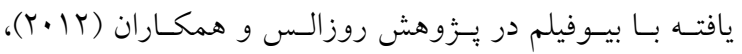

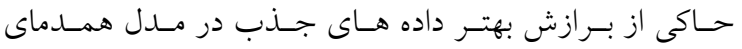
فروندليج (R//9VT) بوده است. اين محققين تشريح نمـوده اند كه كو جكتر بودن ضريب فروندليج (1/n) از عدد يـك نــ تنها حاكى از جذب مطلوب كروم (VI) توسط كلينويتيلولايت يوشـش يافتـهـ بــا بيـوفيلم بــوده، بلكـه نشـان دهنــده توزيـع يكنواخت جايخاه هاى جذب در سطح جاذب يـا بـه عبـارت ديخر كاهش خطى برهمكنش موجود بين جاذب و كروم (VI)

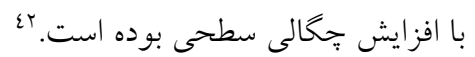

\section{نتيجه گيرى}

مطالعه حاضر نشان داد كه بهره گيرى از گنجايش جـذبى بيوفيلم باكترى سودوموناس آئروثزينوزا براى باكسازى فلـزات

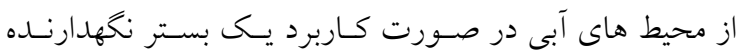
مناسب جون كلينويتيلولايت و بهينه سـازى عوامـل مـوثر بـر راندمان باكسازى، از كارآيى مناسـبى برخــوردار اسـت و مسى تواند راهكارى مناسـب بــراى مــديريت هوشـمندانه بيـوفيلم باكترى ها در تاسيسات تصفيه يِاب باشد.

\section{References}

1. Akhondi A, Khodadadi Darban A, Ganjidoust H. The Effectiveness of Electrocoagulation process for the Removal of Cadmium from Water. J Water Wastewater 2013; 2: 86-93[In Persian].

2. Dermentzis K, Christoforidis A, and Valsamidou E. Removal of nickel, copper, zinc and chromium from synthetic and industrial wastewater by electrocoagulation. J Environ Sci 2011; 1(5): 112-119.

3. El.Bestawy E, Abu Rass M, Abdel-Kawi MA. Removal of lead and oil hydrocarbon from oil refining-contaminated wastewater using Pseudomonas spp. J Nat Sci Res 2013; 3(11): 112-124.

4. Maleki A, Khadem Erfan MB, Mohammadi AS, Ebrahimi R. Application of commercial powdered activated carbon for adsorption of carbolic acid in aqueous solution. Pak J Bio Sci 2007; 10(14): 2348-2352.

$$
\begin{aligned}
& \text { است. ^^ } \\
& \text { كاهش آرام و تدريجى راندمان پاكسازى با افـزايش دمـاى } \\
& \text { محيط واكنش در اين تحقيـق حـاكى از كرمـازا بــودن فرآينـد } \\
& \text { جذب نيكل توسط بيوفيلم است. افـزايش دمـا ممكـن اسـت } \\
& \text { نيروهاى جذبى بين گونه هاى آناليت و مكان هاى فعـال روى } \\
& \text { سطح جاذب را كـاهش داده وسـبب كـاهش ظرفيـت جـــب }
\end{aligned}
$$

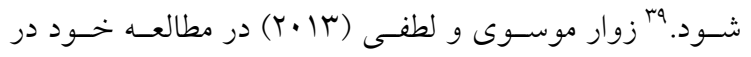

$$
\begin{aligned}
& \text { خصوص حذف نيكل و كادميوم از محلول هـاى آبسى توسـط } \\
& \text { نانو ذرات مغناطيسى اصلاح شده به نتايجى مشابه دست يافته }
\end{aligned}
$$

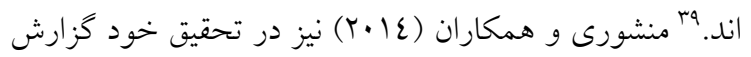

$$
\begin{aligned}
& \text { نموده اند كه راندمان ياكسازى سرب توسط ير شترمرغ اصلاح } \\
& \text { شده با يراكسيد هيدروزن با افزايش دما تا ·ع درجه سانتيخراد، }
\end{aligned}
$$

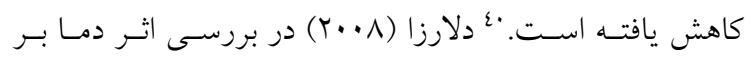

$$
\begin{aligned}
& \text { جذب زيستى سرب به نتايج مشابهى دست يافته است. اء } \\
& \text { برازش بهتر داده هاى نيكل توسط بيوفيلم استقرار يافته بر }
\end{aligned}
$$

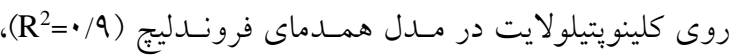

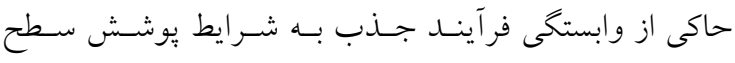

$$
\begin{aligned}
& \text { جاذب بوده است و ضريب n معادل 1/109 در اين مدل، نشان } \\
& \text { دهنده جذب مناسب اين فلز بـر روى جـاذب اسـت. مطالعـه } \\
& \text { همدماهاى جذب كروم (VI) توسـط كلينويتيلولايست يوشـش }
\end{aligned}
$$

5. Quintelas C, Fernades B, Castro J et al. Biosorption of Cr (VI) by a Bacillus coagulans biofilm supported on granular activated carbon (GAC). Chem Eng J 2008; 136(2-3): 195-203.

6. Lameiras S, Quintelas C, Tavares T. Biosorption of Cr (VI) using a bacterial biofilm supported on granular activated carbon and on zeolite. J Bioresour Technol 2008; 99(4): 801-806.

7. Harrison JJ, Ceri H, Turner RJ. Multimetal resistance and tolerance in microbial biofilms. Nat Rev Microbiol 2007; 5(12): 928-938.

8. Malik A. Metal bioremediation through growing cells. Environ Int 2004; 30(2): 261-278.

9. Quintelas C, Rocha Z, Silva B et al. Biosorptive performance of an Escherichia coli biofilm supported on 


$$
\text { رقيه سادات صالحنزاد و ميترا عطآبادى }
$$

zeolite NaY for the removal of Cr (VI), Cd (II), Fe (III) and Ni(II). Chem Eng J 2009; 152(1): 110-115.

10. Mangwani N, Shukla SK, Rao TS, Das S. Calciummediated modulation of Pseudomonas mendocina NR802 biofilm influences the phenanthrene degradation. Colloild surf B Biointerfaces 2014; 114(1): 301-309.

11. Comte S, Guibaud G, Baudu M. Biosorption properties of extracellular polymeric substances (EPS) towards Cd, Cu, and $\mathrm{Pb}$ for different $\mathrm{pH}$ values. J Hazard Mater 2008; 151(1): 185-193.

12. Eboigbodin KE, Biggs CA. Characterization of the extracellular polymeric substances produced by Escherichia coli using infrared spectroscopic, proteomic, and aggregation studies. Biomacromolecules 2008; 9(2): 686-695

13. Maleki A, Mahvi AH, Rezaei R, Sherzadsepini M. Cadmium adsorption by a bacterial biofilm supported on clinoptilolite from aqueous solution. Scientific J Kurdistan Univ Med Sci 2013; 16: 65-75. [In Persian].

14. Kocaoba S, Orhan Y, Akyüz T. Kinetics and equilibrium studies of heavy metal ions removalby use of natural zeolite. Desalination 2007; 214(1-3): 1-10.

15. AnsariMahabadi A, Hajabbasi MA, Khademi $\mathrm{H}$, Kazemian H. Soil cadmium stabilization using an Iranian natural zeolite. Geoderma 2007; 137: 388-393 [In Persian].

16. Mohammadi Sani M, Astaraei A, Fotovat A, Lakziyan A. Inactivation of Lead and Zinc in Mine Waste using Zeolite and TSP and its effect on wheat growth. Iran. J Field Crops Res 2011; 8(6): 956-964 [In Persian].

17. Movahedian Atar H, Ebrahimi A. Evaluation of natural zeolite and artificial Resins the removal of nickel, zinc and copper from industrial wastewater. J Res Med Sci 2002; 8(4): 75-80 [In Persian].

18. Quintelas C, Tavares T. Removal of chromium (VI) and cadmium (II) from aqueous solution by a bacterial biofilm supported on granular activated carbon. Biotechnol Lett 2001; 23(16): 1349-1353.

19. Kang SY, Bremer PJ, Kim KW, McQuillan AJ. Monitoring metal ion binding in single layer Pseudomonas aeruginosa biofilm using ATR-IR spectroscopy. Langmuir 2006; 22(1): 286-291.

20. Yolmeh M, Habibi Najafi MB, Farhoosh R, Hosseini F. Application of response surface methodology to optimize Ultrasound-assisted extraction conditions of dye from annatto seeds. J Food Sci Technol. 2016; 13(50): 41-51.

21. Ataabadi M, Tahmourespour A, Hoodaji M, et al. The role of exopolysaccharides from a chromate reducing Pseudomonas aeruginosa in resistance to hexavalent chromium and antibiotics. J Shahrekord Univ Med Sci 2014; 16(4): 28-38 [In Persian]
22. Amoozegar MA, Ghazanfari N, Didari M. Lead and cadmium bioremoval by Halomonas sp., an exopolysaccharide-producing halophilic bacterium. J Environ Sci Technol 2012; 11(4): 479-491.

23. Silva B, Figueiredo H, Quintelas C, et al. Zeolites as supports for the biorecovery of hexavalent and trivalent chromium. Microporous Mesoporous Mater 2008; 116(13): 555-560.

24. Yegane badi M, Esrafili A, Rezaei Kalantary R, et al. Removal of Diethyl phthalate from Aqueous Solution Using Persulfate-based (UV / $\mathrm{Na}_{2} \mathrm{~S}_{2} \mathrm{O}_{8} / \mathrm{Fe}^{2+}$ ) Advanced Oxidation Process. J Mazandaran Univ Med Sci 2015; 25(132): 122-135 [in Persian].

25. Marzan LW, Hossain M, Mina SA, et al. Isolation and biochemical characterization of heavy-metal resistant bacteria from tannery effluent in Chittagong city, Bangladesh: Bioremediation viewpoint. Egyptian J Aqua Res 2017; 43(1):65-74.

26. Mohammadzadeh Karkaragh R, Chorom M, Motamedi H,

Mohabat A. Biosorption and bioaccumulation of $\mathrm{Cd}$ and $\mathrm{Ni}$ in competitive solution by three bacteria isolated from polluted soils to sewage sludge. J Microbial World 2014; 7(3): 241-251 [In Persian].

27. Raja CE, Anbazhagan K, Selvam GS. Isolation and characterization of a metal-risistant Pesudomonas aeruginosa strain. World J Microbiol Biotecnol 2006; 22(2): 577-585.

28. Jasmine R, Venkadesan B, Ragul K. Identification and characterization of heavy metal- resistant Pesudomonas aeruginosa and its potential for bioremediation. Am J Pharma Tech Res 2012; 22(4): 1-6.

29. Teitzel GM, Parsek MR. Heavy metal resistance of biofilm planktonic Pseudomonas aeruginosa. Appl Environ Microbiol 2003; 69(4): 2313-2320.

30. Wan Ngah W S, Hanafiah MAKM. Adsorption of copper on rubber (Hevea brasiliensis) leaf powder: Kinetic, equilibrium and thermodynamic studies. Biochem Eng J 2008; 39(3): 521-530.

31. Horsfal Jr M, Ogban F, Akporhonor EE. Sorption of chromium (VI) from aqueous solution by cassava (Manitol sculenta Cranz.) waste biomass. Chem Biodivers 2006; 3(2): 161-173.

32. Ghorbani F, Younesi H. Biosorption of cadmium (II) ions by Saccharomyces cerevisiae biomass from aqueous solutions.J Water Wastewater 2008; 68, 33-39 [In Persian]

33. Heydari A, Younesi H, Mehraban Z. Removal of Cd, $\mathrm{Ni}$ and $\mathrm{Pb}$ from aqueous solutions using NH2-MCM-41 adsorbent. Water Wastewater 2011; 21(1): 25-33 [In Persian]

34. Marandi R, Doulati Ardejani F, Amir afshar H. Biosorption lead(II) and zinc(II) by pre-treated biomass of Phanerochaete chrysosporium. Int J Mining Environ 
Issues 2010; 1(1): 196-207

35. Sedighi M, KHosravi V, Rahdani A. Estimating the impact of important parameters on biosorption of $\mathrm{Cu}$ and Mn ions by Bacillus Thuringiensis. New Cell Mol Biotechnol J 2011; 2(8): 45-51. [In Persian]

36. Asman Rafat M, Tabatabaei $\mathrm{H}$, Noshadi M, Beagi Harghegani $\mathrm{H}$. Liquid phase adsorption of $\mathrm{Ni}, \mathrm{Cd}$ and $\mathrm{Pb}$ on zeolite as affected by zeolite size and concentration of solution. J Water Soil Sci 2014; 18(68): 23-30 [In Persian].

37. Esmaeili A, Ghasemi S. Evaluation of the marine algae Gracilaria and its activated carbon for the adsorption of Ni(II) from wastewater. World Appl Sci J 2009; 6 (4): 515-18.

38. Ataabadi M. 2014. Investigation of chromate absorption on surface modified zeolite with iron nanoparticles and bacterial biofilm. Doctoral thesis of Soil Sciences Department of Islamic Azad University, Isfahan
(Khorasgan) Branch.

39. Zavarmosavi H, Lotfi Z. Removal of Nickel and Cadmium from Aqueous Solution by Modified Magnetic Nanoparticles. J Water Wastewater 2013; 1: 2-11. [In Persian]

40. Manshori M, Yazdanbakhsh A, Daraei H, Norisepehr M. Lead removal from aqueous solution using ostrich feathers modified by hydrogen peroxide. J Hormozgan Univ Med Sci 2014; 17(4): 307-315 [In Persian]

41. De la Rosa G, Reynel-Avila HE, Bonilla A, et al. Recycling poultry feathers for $\mathrm{Pb}$ removal from wastewater: Kinetic and equilibrium studies. Int J Chem Mol Eng 2008; 47: 394-402.

42. Rosales E, Pazos M, Sanroman MA, Tavares $T$. Application of zeolite-Arthrobacter viscosus system for the removal of heavy metal and dye: Chromium and Azure B. Desalination. 2012; 284:150-156. 